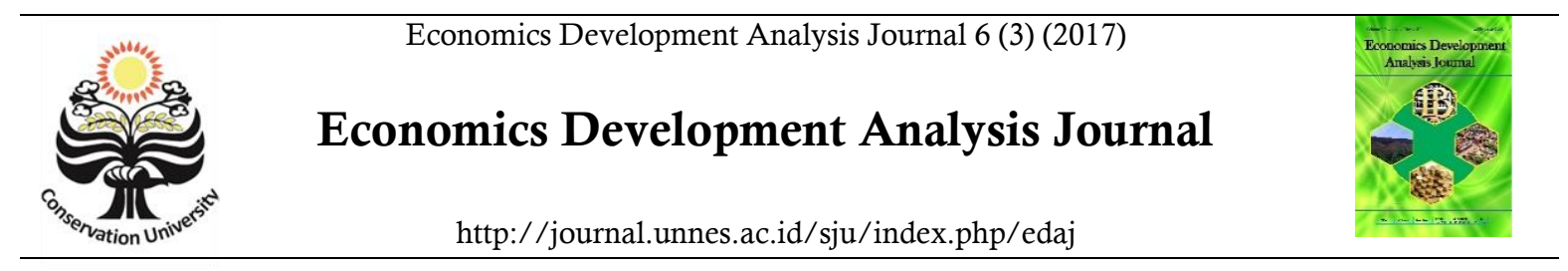

\title{
Zakat Distribution Role in Reducing People Poor Number in Semarang City
}

\author{
Nura Yuli Fadhilahningrum ${ }^{\circledR}$, Karsinah $^{2}$
}

Economics Development Department, Economics Faculty, Universitas Negeri Semarang

\begin{tabular}{|c|c|}
\hline Article Info & Abstract \\
\hline $\begin{array}{l}\text { Article History: } \\
\text { Received April } 2017 \\
\text { Accepted Juny } 2017 \\
\text { Published Agust } 2017\end{array}$ & $\begin{array}{l}\text { Poverty is one of the main problems facing Indonesia to date, as the capital of Central Java City } \\
\text { Semarang also can not be separated from this poverty problem. Although the number of poor people } \\
\text { from year to year decline, but in terms of proportion to the total population of Semarang City, the } \\
\text { number of poor people reached } 20 \% \text {. One instrument that can help reduce poverty is zakat. This } \\
\text { study aims to analyze the impact of zakat as poverty reduction with zakat approach and with zakat. }\end{array}$ \\
\hline $\begin{array}{l}\text { Keywords : } \\
\text { Islamic Poverty Index, } \\
\text { CIBEST Model, } \\
\text { Productive Zakah, }\end{array}$ & $\begin{array}{l}\text { The analytical tool used in this research is poverty indicator consisting of headcount ratio, poverty } \\
\text { gap index, income index gap, Sen index and FGT (Foster, Greer, Thorbecke) index and CIBEST } \\
\text { Index. The find show that zakat can reduce the poverty rate and also can improve the level of welfare } \\
\text { of a family, both material and spiritual. }\end{array}$ \\
\hline
\end{tabular}

Number of Poor 


\section{INTRODUCTION}

The category of Indonesia that is still in the stage of developing countries makes Indonesia can not escape from the problem of poverty. The poverty cycle occurring in Indonesia is due to the lack of the poor to obtain capital. The current economic system that is not pro-poor is suspected to be the cause of the difficulty of reducing poverty in Indonesia. Financial institutions as intermediary institutions that channel funds from people with a surplus of funds to people with a deficit of funds do not function well, this is evident from the many societies that are unbankable, because they do not have assets for collateral as the basis of credit loans, and the lack of entrepreneurial skills also caused the poor to get out of poverty. (Pratama, 2015)

Zakat has many important roles as well as acceptable benefits, whether for muzakki (giver of zakat) or for mustahik (recipient of zakat). In this case, zakat is expected to make income evenly distributed between the surplus with the deficit party, even can make the deficit party becomes surplus party (Huda, Idris, Nasution, Wiliasih, 2009).

The Government of Indonesia has authorized the establishment of zakat amil institutions charged with accepting zakat that must be paid by Muslims who have more wealth or wealth, one of the institutions collecting zakat under the auspices of the government is BAZNAS.

BAZNAS as collecting and distributing institutions of zakat has a program in which zakat is not only in the form of consumptive, but also productive zakat. Zakat productive is aimed at those who have business, but in the development of business has constraints in terms of capital so that productive zakat this is the solution of this problem.

The city of Semarang as the capital of Central Java also can not be separated from the problem of poverty. Data collected from SIMGAKIN (Poor Management Information System) states that in 2015 the population percentage of the number of poor people in
Semarang City reached $20,85 \%$ of the total population in Semarang City, this percentage indicates that the city of Semarang still has residents in the plight is big enough.

The poverty rate in Semarang is still quite high. This happens because the income distribution widened the gap between rich and poor (Muktiali et al, 2012) The transfer of funds through zakat can be a solution to narrow the gap, which from the narrowing can reduce the number of poor people in Semarang City.

Overcoming poverty in Semarang City with zakat as an instrument needs a professional body to megatur distribution of zakat productively, which later can make a meaningful contribution for poverty alleviation problem. One of zakat managing agency that tries to overcome the problem of poverty especially in Semarang City that is BAZNAS Semarang City.

BAZNAS Semarang City has a mission to empower and improve the welfare of the economically weak (dhu'afa). The form of the implementation of the mission is with the program distribution program accompanied by mentoring, which in this case can support in reducing the number of poor people in Semarang City. BAZNAS Semarang City in conducting the distribution of zakat also perform monitoring to the recipients of zakat, so that funds that have been distributed can be utilized maximally in developing the business. This productive zakat distribution program can be an instrument in relation to reducing the number of poor people in Semarang City.

Zakat management should have a good system, the system not only includes the collection of zakat but also must have an impact in reducing the level of poverty (Anriani, 2010).

The existence of productive zakat distribution BAZNAS Semarang City and the high number of poor people in Semarang City are two main things that can be interrelated as a form of the existence of problems and solutions, namely the distribution of productive zakat as a solution of the problem of poverty rate Semarang city is still high. 


\section{RESEARCH METHOD}

The type of this research is quantitative research, with research data consist of two namely primary data and secondary data. The population in this study is all the poor people in Semarang City, and from the population are samples using purposive sampling taking technique with the following criteria requirements (1) The sample is a poor resident of Semarang City receiving Zakat from BAZNAS Semarang City. (2) Samples are the recipients of the zakat distribution program of Semarang Makmur BAZNAS Semarang City in 2016

Can we take about 31 sampels basic on criteria above.Data analysis method used in this research use general poverty index and index of poverty of islami. The general poverty index consists of the headcount ratio, the poverty gap index, the income gap index, the Sen index and the FGT (Foster, Greer, Thorbecke) index and the index of Islamic poverty are the CIBEST quadrant models.

The purpose of the headcount ratio $(\mathrm{H})$ measures the number of poor as a percentage of the population observed. This value of $\mathrm{H}$ is in the range of 0 to 1 . The closer to 0 , the number of families mustahik who are below the poverty line less and less. And conversely, the closer to 1 then the number of families who are below the poverty line is getting bigger. Poor categories are based on poverty line standards. A person is categorized as poor if his income is below the poverty line. The poverty line used is the official standard of a country. In Indonesia, the prevailing poverty line is the poverty line issued by the Central Bureau of Statistics (Anriani, 2010). The formula for the headcount ratio is as follows:

$\mathrm{H}=\frac{q}{n}$

Information:

$\mathrm{H}=$ Headcount ratio

$\mathrm{q}=$ Number of mustahik families that are below the poverty line

$\mathrm{n}=$ Number of families observed $\mathrm{b}$. Poverty Depth Index

The Poverty gap index (P1) is used to measure the depth of poverty found in a community or country by calculating the difference between the aggregate income of the poor who are below the poverty line and the poverty line. The smaller the index value, the less the difference between the aggregate income of the poor and the existing poverty line, which indicates that the welfare of the community is improving. P1 is also used as a basis for the government in determining the policy of cash transfer or government to people transfer (Beik and Arsyianti, 2015). The formula used is as follows:

$\mathrm{P} 1=\sum_{\mathrm{i}=1}^{\mathrm{q}} \frac{\mathrm{z}-\mathrm{y}_{\mathrm{i}}}{\mathrm{q}}$

Information:

$\mathrm{P} 1$ = Poverty gap index

$\mathrm{z}=$ Poverty line

$\mathrm{yi}=$ Individual income $\mathrm{i}$

$q=$ Number of mustahik families that are below the poverty line

The next calculation is about the income gap index (I). This calculation is used to see the average percentage of poor people who are below the poverty line. The smaller the value of this ratio, the fewer poor people in the community (Anriani, 2010). The formula for this index is as follows:

$\mathrm{I}=\sum \mathrm{i}=\in \mathrm{S}(\mathrm{z}) \frac{\mathrm{g}_{\mathrm{i}}}{\mathrm{q}_{\mathrm{z}}}$

Information:

$\mathrm{I}=$ Income gap ratio

gi $=\mathrm{z}-\mathrm{yi}$, Increment of the income of the poor person to the poverty line

$\mathrm{z}=$ Poverty line

$\mathrm{yi}=$ Individual income $\mathrm{i}$

$q=$ Number of mustahik families who are below the poverty line

Poverty Severity Index

The Poverty Severity Index provides an overview of the spread of expenditure among the poor. The higher the index value, the higher the inequality of expenditure among the poor (BPS, 2015). The measuring tool used to calculate the poverty severity index is Sen index (P2) and FGT index (P3). The formula used in calculating the Sen index is as follows:

$\mathrm{P} 2=\mathrm{H}\left[\mathrm{I}+\left(\right.\right.$ 1- I) $\left.\mathrm{G}_{\mathrm{p}}\right]$

Information:

$\mathrm{P} 2=$ Sen index 
$\mathrm{H}=$ Headcount ratio

$\mathrm{I}=$ Income gap index

$\mathrm{Gp}=$ Gini coefficient

The above formula combines three indices at once namely Headcount ratio, Income gap index, Gini coefficient. The index also calculates the impact of income transfer on the poor.

The severity of poverty can then be measured using the FGT Index is to know how big the impact of the existence of a program in reducing the number of poor people. The formula for calculating the FGT Index is :

$\mathrm{P} 3=\frac{1}{\mathrm{n}} \sum_{\mathrm{i}=1}^{\mathrm{q}}\left(\frac{\mathrm{z}-\mathrm{y}_{\mathrm{i}}}{\mathrm{z}}\right) \alpha$

Information:

P3 = FGT index

$\mathrm{n}=$ number of families observed

$\mathrm{z}=$ poverty line

$\mathrm{yi}=$ individual income $\mathrm{i}-\mathrm{i}$

The parameter value $\alpha$ shows the level of sensitivity to income distribution among the poor, in this study using $\alpha$ value equal to 1 to see the FGT index value.

\begin{tabular}{|c|c|c|}
\hline $\begin{array}{l}\quad \text { Sk } \\
\text { or } \\
\text { Aktual }\end{array}$ & $\begin{array}{c}\leq \\
\text { Nilai MV }\end{array}$ & >Nilai MV \\
\hline $\begin{array}{c}> \\
\text { Nilai SV }\end{array}$ & \begin{tabular}{l}
\multicolumn{1}{c}{ Kaya } \\
Spiritual, \\
Miskin \\
Material \\
(Kuadran II)
\end{tabular} & $\begin{array}{r}\text { Kaya } \\
\text { Spiritual, Kaya } \\
\text { Material } \\
\text { (Kuadran I) }\end{array}$ \\
\hline $\begin{array}{r}\leq \\
\text { Nilai SV }\end{array}$ & $\begin{array}{l}\text { Miski } \\
\text { spiritual,Mis } \\
\text { kin Material } \\
\text { (Kuadran } \\
\text { IV) }\end{array}$ & \begin{tabular}{l}
\multicolumn{2}{c}{ Miskin } \\
Spiritual, $\quad$ Kaya \\
Material (Kuadran \\
III)
\end{tabular} \\
\hline
\end{tabular}

Source : Beik dan Arsyianti (2015)

Before placing the observed families into the CIBEST quadrant, the values of MV and SV must be known first. in this study, the value of MV used comes from the value of Poverty Line issued by BPS in the period 2015 which amounted to Rp. 368,477 for GK before zakat and Rp. 382,160 for GK stelah zakat. The per capita poverty line is multiplied by the number of family members, making it the value of the MV (Material Poverty Line). While the fulfillment of spiritual needs is calculated from the standard fulfillment of five variables, namely the score of prayer worship, zakat, fasting, family / household environment scores, and government policy scores. To assess the scores on each of these variables Likert scale is used between 1 and 5. Furthermore, the calculation of spiritual score of households / families according to Beik and Arsyianti (2015) is based on the following formula:

$\mathrm{Hi}=\frac{\mathrm{Vp}+\mathrm{Vf}+\mathrm{Vz}+\mathrm{Vh}+\mathrm{Vg}}{5}$

Information:

$\mathrm{Hi}=$ actual score of i-family

$\mathrm{Vp}=$ prayer score

$\mathrm{Vf}=$ fasting score

$\mathrm{Vz}=$ zakat score and infak

$\mathrm{Vh}=$ family environment score

$\mathrm{Vg}$ = government policy score

From the calculation of the above formulas and from the results of the cibest quadrant that has been obtained, can be calculated welfare index (quadrant I), material poverty index (quadrant II), spiritual poverty index (quadrant III) and absolute poverty index (quadrant IV). According to Beik and Arsyianti (2015), the formulas are:

Welfare index

$\mathrm{W}=\frac{\mathrm{w}}{\mathrm{n}}$

Information :

$\mathrm{W}=$ welfare index; $0 \leq \mathrm{W} \leq 1$

$\mathrm{w}=$ Number of prosperous families (rich in material and spiritual)

$\mathrm{N}=$ Number of population (number of families observed)

Material poverty index

$\operatorname{Pm}=\frac{\mathrm{Mp}}{\mathrm{N}}$

Information :

$\mathrm{Pm}=$ Material poverty index; $0 \leq \mathrm{Pm} \leq 1$

$\mathrm{Mp}=$ The number of poor families materially but spiritually rich

$\mathrm{N}=$ Total number of population (total of family observed)

3. The index of spiritual poverty 
$\mathrm{Ps}=\frac{\mathrm{Sp}}{\mathrm{N}}$

Information :

Ps = Index of spiritual poverty; $0 \leq \mathrm{Ps} \leq 1$

$\mathrm{Sp}=$ Number of spiritually poor but materially

rich families

$\mathrm{N}=$ Number of population (total of family observed)

4. The absolute poverty index

$\mathrm{Pa}=\frac{\mathrm{Ap}}{\mathrm{N}}$

Information :

$\mathrm{Pa}=$ absolute poverty index; $0 \leq \mathrm{Pa} \leq 1$

$A p=$ Number of poor families spiritually or materially

$\mathrm{N}=$ Number of population (total of family observed).

\section{RESULTS AND DISCUSSION}

Here presented the results of research to the productive zakat alms BAZNAS Semarang city based on the calculation of general poverty index, can be seen in the following table:

\begin{tabular}{lll}
\hline Poverty & Before Zakah & After Zakah \\
Parameter & Distribution & Distribution
\end{tabular}

\begin{tabular}{lll}
\hline $\mathrm{H}$ & 0,387 & 0,226 \\
$\mathrm{P} 1$ & 357241 & 277600
\end{tabular}

\begin{tabular}{lll} 
I & 0,24 & 0,18 \\
P2 & 0,15 & 0,07 \\
P3 & 8,5 & 1,6 \\
\hline
\end{tabular}

Source : Primary Data

Based on the above table, the headcount ratio index value before zakat distribution is 0.387, which means that from all households there are 39 percent of families that are categorized as poor based on family poverty line. The presence of productive zakat distribution program BAZNAS Semarang city of Semarang Makmur Bina Mitra Mandiri causes the headcount ratio value to decrease from 0.387 to 0.226 . This shows that the distribution of zakat has a positive impact, because it is able to reduce the number of mustahik living with income below the poverty line of 41.7 percent.
The index value of poverty gap or poverty

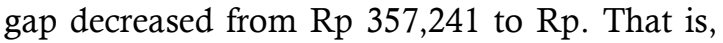
before the distribution of zakat, the distance between the average income of poor households is impossible with the poverty line is $\mathrm{Rp} 277,600$. With the zakat distribution program from BAZNAS Semarang City, this distance can be reduced to $\mathrm{Rp} 277,600$. The 22.3 percent decline indicates that the zakat distribution conducted by BAZNAS Semarang City empirically able to reduce the level of family poverty gap mustahik.

The same is true of the income gap index where the income gap index falls from before zakat distribution by 0.24 to 0.18 after zakat distribution. This shows the existence of zakat can reduce the value of the income gap ratio of 43.73 percent. Thus, it can be concluded that the level of depth of poverty can be reduced because of the distribution program of Zakat BAZNAS Semarang City.

Index value is an indicator in measuring the impact of income transfer on the poor. Income transfer in this study is productive productive charity semarang BAZNAS Semarang. The result of the research to productive zakat mustahik shows that the value of sen of index before the distribution of productive zakat is equal to 0,15 and after the distribution of productive zakat BAZNAS Semarang value of sen sen value down to 0,07 . It can be concluded that with the distribution of productive zakat this gives the impact of reducing the severity of poverty by $80 \%$. It is directly proportional to the value of FGT which also decreased after the existence of the productive zakat distribution of BAZNAS Semarang City which initially was 8.5 then to 1.6 or changed by $80 \%$. FGT Index can measure the success of a poverty program can reduce the number of poverty and gap among the poor, in other words productive zakat distribution program BAZNAS Semarang city is considered successful because of the decline in the value of FGT Index.

After calculations based on the general poverty index can then be analyzed using the Islamic poverty index. This calculation uses the CIBEST quadrant. In this quadrant is indicated the family grouping mustahik based on indicator 
of material condition and spiritual condition. The results of the calculation are as follows:

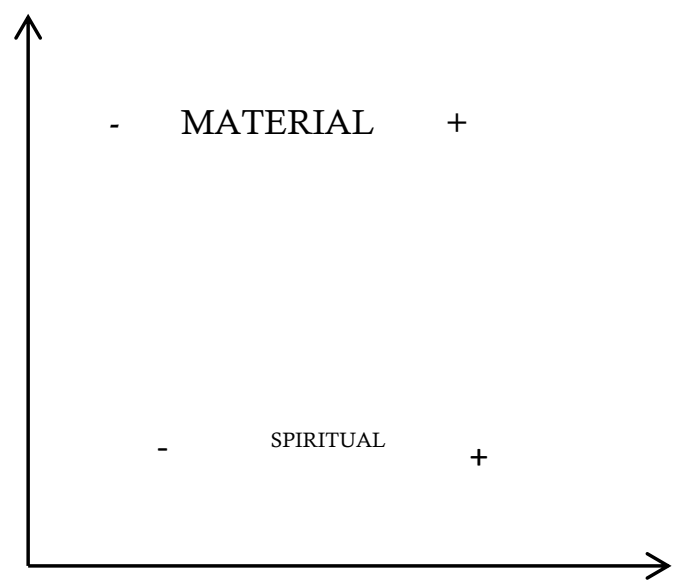

\begin{tabular}{|l|l|l|l|}
\hline \multicolumn{2}{|l|}{$\begin{array}{l}\text { Kuadran } \\
\text { II }\end{array}$} & \multicolumn{2}{l|}{ Kuadran } \\
\hline Tanpa & Dengan & Tanpa & Dengan \\
Zakat & Zakat : & Zakat : & Zakat: \\
$: 12$ & 7 & 15 & 24 \\
\hline Kuadran IV & \multicolumn{2}{|l|}{ Kuadran III } \\
\hline \multicolumn{2}{|l|}{} & Dengan & \multicolumn{2}{|l|}{ Dengan } \\
Tanpa & Zakat: & Tanpa & Zakat: \\
Zakat: 0 & 0 & Zakat: 4 & 0 \\
\hline
\end{tabular}

The quadrant above explains the level of fulfillment of the material and spiritual needs of the productive zakat mustahik. The above quadrant shows that

there is a positive change of each CIBEST quadrant before the zakat and after the zakat there is a change of spiritual and material condition of each quadrant.

Quadrant IV is a quadrant that shows the absolute poverty condition, a condition that indicates that a person is in poor condition spiritually and poorly material. Research conducted to the productive zakat alms BAZNAS Semarang City shows the absence of mustahik that is in absolute poor condition, either before the productive zakat or after the existence of productive zakat.

The intersection of the third quadrant is that if one is in this quadrant grouping, it indicates that the person has not been able to fulfill the spiritual needs but can be materially fulfilled, or in other words indicates the poor spiritual and the material rich. Research shows that there is a change in the number of productive productive zakat BAZNAS Semarang City, which initially before receiving the distribution of productive zakat is as much as 4 families mustahik, and after the existence of productive zakat there is no mustahik that in poor spiritual condition. Research shows that, mustahik feel more grateful with the help given by BAZNAS Semarang City so that affect the spiritual condition possessed by the mustahik.

Quadrant II indicates that the productive productive zakat BAZNAS of Semarang City which is in this quadrant is mustahik which is in poor condition of material, that is condition indicating that mustahik can fulfill requirement from spiritual aspect or SV.3 value, while in fulfilling requirement from material aspect still less, or less income level than the prevailing household GK. The result of research on the mustahik household BAZNAS Semarang City shows that there is a change to the second quadrant, that is before the existence of productive zakat is as much as 12 mustahik and after the zakat decreases to 7 mustahik, meaning that with the distribution of productive zakat BAZNAS Semarang give change from material facet.

This quadrant explains that the mustahic within this quadrant is mustahic in a rich, spiritual and material rich condition, embedded in the spiritual rich is the $\mathrm{SV}>3$ value, and the material rich here is the amount of household income in excess of the prevailing household GKM this is exceeding the value of $1,473,908$ million rupiahs, for the parameter of value before productive zakah is distributed and exceeds the value of $1,528,640$ million rupiah for the parameter of $\mathrm{MV}$ value after the distribution of zakat. The results of the research to the productive zakat mustahik indicate that there is a change in this quadrant, before and after the distribution of productive zakat to the mustahik. The change is by the addition of 9 mustahik, which initially is as much as 15 mustahik and after the existence of zakat is equal to 24 mustahik. These results indicate that with the 
distribution of productive zakat program Semarang Makmur Bina Mitra Mandiri BAZNAS Semarang City can improve the welfare of the mustahik.

Table Change of CIBEST Index Value

\begin{tabular}{llll}
\hline INDEKS & Nilai & Nilai & Pres \\
CIBEST & $\begin{array}{l}\text { Indeks } \\
\text { Sebelum } \\
\text { Zakat }\end{array}$ & $\begin{array}{l}\text { Indeks } \\
\text { Setelah } \\
\text { Zakat }\end{array}$ & $\begin{array}{l}\text { se } \\
\text { Peru } \\
\text { baha } \\
\mathrm{n}\end{array}$ \\
& & & $42 \%$ \\
& 0,387 & 0,226 & \\
\hline $\begin{array}{l}\text { Indeks } \\
\text { Kemiskinan } \\
\text { Material }\end{array}$ & & & 100 \\
$\begin{array}{l}\text { Indeks } \\
\text { Kemiskinan } \\
\text { Spiritual }\end{array}$ & 0,129 & 0 & $0 \%$ \\
$\begin{array}{l}\text { Indeks } \\
\text { Kemiskinan } \\
\text { Absolut }\end{array}$ & 0 & 0 & \\
$\begin{array}{l}\text { Indeks } \\
\text { Kesejahteraan }\end{array}$ & 0,548 & 0,774 & $41 \%$ \\
\hline
\end{tabular}

Source : Primary Data, 2017

The table above shows that the material poverty index before receiving zakat and after receiving zakat did not change, the index value before receiving zakat was 0.387 , then decreased by $42 \%$ and this index became 0.226 after the zakat. The occurrence of this index decline is the impact of the existence of productive zakt distribution BAZNAS Semarang City, the presumption mustahik productive zakat states that with the existence of productive zakat the mustahik feel helped.

The mustahiq spiritual poverty index before zakat is 0.129 . After zakat follow the value of the index of spiritual poverty is equal to 0 or no mustahiq who experience spiritual poverty, in other words the recipient household of zakat able to meet the spiritual needs. It can be concluded in this case that the guidance made by BAZNAS employees to the beneficiaries of zakat (mustahiq) is effective.

Mustahiq who are in absolute poverty condition in this study either from before the zakat or after the existence of large zakat value is 0 . This indicates that the respondents in the study or in this case the recipients of zakat no one in absolute poverty conditions, namely the condition of material poverty and spiritual.

The welfare index of the recipients of zakah before receiving zakat is 0.548 , and after receiving zakat from BAZNAS Semarang City is 0.774 or up by 41 percent. This shows that after the distribution of zakat to the mustahiq there are 41 percent of mustahiq households capable of meeting both material and spiritual needs at the same time.

\section{CONCLUSION}

Distribution of productive zakat can reduce the number of poor people in Semarang City, when viewed from the indicator of general poverty. The value of the headcount ratio decreasing from before zakat is 0.387 to 0.226 after zakat, the poverty depth value measured by Poverty Gap Index (P1) and Income Gap Transfer (I) also decreased from before and after the distribution of zakat that is equal to $22 \%$ for $\mathrm{P} 1$ and by $25 \%$ for the value of I. The decline also occurs on the poverty severity as measured by Sen Index (P2) and FGT Index (P3). Sen Index before zakat is equal to 0,152 and 0,07 after zakat and $\mathrm{P} 3$ value also decrease $81 \%$. Measurement of the role of productive zakat to the number of poor people in Semarang City can be seen from CIBEST quadrant. The number of households in quadrant I CIBEST increases after the giving of zakat, which is 15 families before the zakat and increased to 24 families after the zakat, indicating the success of zakat in increasing the number of families into prosperous families in material and spiritual. The reduction of the number of poor families in quadrant III is also an indication that with the existence of zakat can reduce material poverty. In addition, the decline of families in quadrant III from before the zakat is a number of 4 families and after the zakat there is no family residing in this quadrant. This indicates that zakat can also improve the spiritual condition of a family. 


\section{REFERENCES}

Anriani. 2010. Analisis Dampak Zakat terhadap tingkat Kemiskinan Mustahik (Studi Kasus:Pendayagunaan Zakat oleh BAZ Kota Bogor di Tiga Kecamatan Kota Bogor).Skripsi.: Institut Pertanian Bogor.

BAPPEDA Kota Semarang. 2017. Rekapitulasi Warga Miskin Kota Semarang 2015 (online) http://simgakin.semarangkota.go.id/2015/w ebsite/web/rekap_gakin date accessed 14 November 2017

Beik, Irfan Syauqi dan Laily Dwi Arsyianti. 2015. Ekonomi pembangunan syariah. Bogor: PT Penerbit IPB Press.

Huda, N., Idris, H.R., Nasution, M.E., Wiliasih, R. 2009.Ekonomi Makro Islam: Pendekatan Teoretis. Edisi 1. Jakarta: Kencana Prenada Media Group.

Muktiali, Muhammad, dkk. 2012. Kajian Pengaruh Program Penanggulangan Kemiskinan terhadap Masyarakat Miskin di Kota Semarang.

Pratama, Yogi Cindra.2015. PERAN ZAKAT DALAM PENANGGULANGAN KEMISKINAN (Studi Kasus: Program Zakat Produktif Pada Badan Amil Zakat nasional). Jurnal Tauhidinomics 